\title{
BIBLIOTERAPI UNTUK MENINGKATKAN PEMAHAMAN LABELLING NEGATIF PADA SISWA SMP
}

\author{
Amalia Anggraeni \\ SMPN 1 Puri Mojokerto \\ anggraenia091@gmail.com
}

\begin{abstract}
Abstrak
Penelitian ini dimaksudkan untuk meningkatkan pemahaman siswa kelas VII-D terhadap pelabelan negatif di SMP. Indikator pemahaman pelabelan negatif dan pemberian label, pemberian cap negatif yang umum di masyarakat, dan pelabelan negatif yang berhubungan dengan pertemanan. Jenis penelitian ini menggunakan metode kuantitatif dengan menggunakan desain penelitian pre-experimental design dengan bentuk one group pre-test post-test design. Alat pengumpul data yang digunakan adalah angket pelabelan untuk memperoleh data tingkat pemahaman label negatif. Subjek dalam penelitian ini adalah 7 siswa dari kelas VII-D yang memiliki skor rendah dalam pemahaman label negatif. Teknik analisis yang digunakan adalah statistik non-parametrik analisis uji Wilcoxon. Hasil menunjukkan bahwa nilai $\rho=0,018$ lebih kecil dari $\alpha=0,05$, setelah hasil ini kemudian Ho ditolak dan Ha diterima. Hipotesis penelitian ini yang berbunyi "bibliotik dapat meningkatkan pemahaman pelabelan negatif pada siswa kelas VII-D di SMP" dapat dihitung, sehingga dapat digunakan untuk meningkatkan labeling negatif pada siswa kelas VII-D di SMP.
\end{abstract}

Kata Kunci: biblioterapi, pemahaman labelling negatif

\section{Abstract}

This research is intended to improve students' understanding of class VII-D on negative labeling in junior high school. Indicators of understanding of negative labeling and labeling, common negative stamps in society, and negative labeling related to friendship. This research uses quantitative method using preexperimental design design with one group pre-test post-test design. The data collection tool used is the labeling questionnaire to obtain negative label level understanding data. Subjects in this study were 7 students from grade VII-D who had low scores in the understanding of negative labels. The analysis technique used is non-parametric statistics Wilcoxon test analysis. The results show that the value of $\rho=$ 0.018 is smaller than $\alpha=0.05$, after this result then Ho is rejected and Ha accepted. The hypothesis of this study that reads "bibliotics can improve the understanding of negative labeling in grade VII-D students in SMP" can be calculated so that it can be used to increase negative labeling in grade VII-D students in junior high.

Keywords: bibliotherapy, negative labeling understandin

\section{PENDAHULUAN}

Lingkungan sangat memberikan stimulus terbesar dalam kehidupan manusia serta lingkungan yang mengajarkan individu untuk merespon dan melakukan sesuatu, lingkungan merupakan salah satu faktor yang mempengaruhi pembentukan dan perkembangan perilaku individu, baik lingkungan fisik maupun sosio-psikologis (Sarwono, 2014). Dari pernyataan tersebut menunjukkan seberapa pentingnya peranan lingkungan bagi kehidupan bermasayarakat yang tentunya juga membutuhkan saling toleransi atau pemahaman satu sama lain.

Akibat dari kurangnya pemahaman atau toleransi dalam diri individu dapat menyebabkan sebuah permusuhan yang bisa mengarah ke labelling. Labelling muncul sebagai sebuah teori yang disebut teori labelling, lahirnya teori labelling diinspirasi

oleh perspektif interaksionisme simbolik yang diterapkan dalam dunia orang-orang menyimpang (devian) dan telah berkembang sedemikian rupa dengan riset-riset dan pengujiannya dalam berbagai bidang seperti, kriminologi, kesehatan mental, kesehatan, dan pendidikan yang masuk dalam kelompok umum teoriteori Sosiologi (Nur'aini dan Ahmadi, 2015).

Berdasarkan hasil wawancara kepada guru BK di SMP bahwa di kelas VII-D siswa yang memberi julukan negatif kepada temannya sekitar 50\% atau separuh dari jumlah siswa di kelas, terdapat siswa yang yang terancam direkomendasikan untuk pindah sekolah karena kebiasaan masuk sekolah hanya 3-4 kali tiap minggu dan merasa tidak nyaman dengan lingkungannya, hal tersebut bermula dari setiap masuk sekolah ia menangis ketika berangkat hingga berada di kelas, karena kebiasaan itulah temantemannya memberi julukan gembeng dan semakin membuatnya tidak betah di kelas.

Jika dikaitkan dengan teori labelling yang menyatakan bahwa orang berperilaku normal atau tidak normal, menyimpang atau tidak menyimpang, tergantung pada bagaimana orang lain menilainya, penilaian itu ditentukan oleh kategorisasi yang sudah melekat pada pemikiran orang lain. Dengan memberikan label pada diri seseorang, maka akan cenderung melihat dia secara keseluruhan kepribadiannya, dan bukan pada perilakunya satu per satu (Nur'aini dan Ahmadi, 2015). 
Adapun salah satu ciri labelling yaitu tidak berusaha menjelaskan mengapa seseorang tertarik untuk berperilaku menyimpang, tetapi lebih menggali pada terjadinya definisi dan sanksi sosial negatif yang menekan individu sehingga ia terlibat lebih dalam pada suatu tindakan menyimpang. Maka fenomena yang muncul diatas dapat dikatakan sebagai labelling, terkait kasus tersebut adapaun upaya yang sudah dilakukan oleh guru BK SMP namun belum maksimal.

Untuk membantu siswa Perilaku siswa yang memberikan labelling kepada temannya akan memberikan dampak negatif yang ditunjukkan dari hasil perilaku, oleh sebab itu perlunya bantuan untuk mengatasi hal tersebut yaitu dengan memberikan informasi yang akan menjadi wawasan baru, pemikiran baru dan juga dapat mempengaruhi perubahan perilakunya. Salah satu cara untuk memberikan informasi dapat melalui teknik biblioterapi yang merupakan merupakan sebuah instrument terapi yang didesain untuk menghadirkan emosi dan komunikasi yang membutuhkan peningkatan dari treatment pada anak-anak. (Del rio,Asuncion alvarez,dkk, 2016). Serta merupakan aplikasi langsung dari metode membaca untuk mempengaruhi perubahan dalam karakter/perilaku seseorang, hal ini didasarkan pada asumsi bahwa terdapat kesamaan yang kuat antara karakter tokoh cerita dalam buku dengan pembaca (Dewi,2014).

Biblioterapi yang akan diberikan selain untuk meningkatkan minat baca individu atau siswa juga dapat dikaitkan dengan program literasi yang sekarang sudah digalakkan di sekolah. Jika dilihat biblioterapi kelompok lebih efektif terhadap fungsi klien dalam terapi dan sesi mereka dibanding dengan terapi kelompok pada fungsi klien dalam terapi dan sesi kesan mereka (Shechtman,zipora;Shfrir,rivka nir, 2008). Prosedur biblioterapi yang akan dilaksanakan dalam bentuk bimbingan kelompok terbagi menjadi beberapa pertemuan dengan alokasi waktu 60-80 menit yang memiliki tahapan-tahapan meliputi, tahapan berupa pemberian motivasi kepada siswa untuk memberikan semangat. Selanjutnya ada tahap pengenalan bahan bacaan yang akan diberikan kepada siswa dan inkubasi yaitu memberikan waktu pada peserta untuk merenungkan kembali bahan bacaan yang telah dibaca. Lalu ada tahap tindak lanjut yang meliputi diskusi siswa dan yang terakhir adalah evaluasi yang dilakukan sendiri oleh peserta untuk membuat kesimpulan.

Labelling adalah identitas yang diberikan oleh kelompok kepada individu berdasarkan ciri-ciri yang dianggap minoritas oleh suatu kelompok masyarakat. Labelling cenderung diberikan pada orang yang memiliki penyimpangan perilaku yang tidak sesuai dengan norma di masyarakat. Seseorang yang diberi label akan mengalami perubahan peranan dan cenderung akan berlaku seperti label yang diberikan kepadanya (Herimanto dan Winarno, 2008).

Memberi cap pribadi berarti menciptakan gambaran diri yang negatif, kondisi ini merupakan bentuk ekstrim dari terlalu menggeneralisasi. Distorsi kognitif bentuk ini ialah menganggap bahwa nilai individu terletak pada kesalahan yang dibuatnya, bukan pada kelebihan potensi dirinya. Salah memberi cap berarti menciptakan gambaran negatif yang didasarkan oleh emosi yang dialami saat itu. Beck (dalam Qorny, 2015) distorsi kognitif adalah pikiran berlebihan dan tidak rasional yang saat diidentifikasi sebagai kenyataan oleh pasien akan menimbulkan gangguan psikologis, pikiran-pikiran ini tidak nyata namun malah memperkuat sugesti negatif atau emosi buruk mengenai diri kita sendiri, hal-hal yang terdengar rasional dan akurat tapi tidak nyata dan membuat kita merasa buruk. Beck (dalam Qorny, 2015) lebih lanjut mengatakan bahwa klien yang mengalami gangguan emosi cenderung memiliki kesulitan berpikir logis yang menimbulakan gangguan pada kapasitas pemahamnnya.

Pemahaman merupakan suatu proses, cara, perbuatan memahami atau memahamkan (KBBI, 1990). Taksonomi Bloom merujuk pada taksonomi yang dibuat untuktujuan pendidikan, taksonomi ini pertama kali digagas oleh Benjamin S. Bloom pada tahun 1956. Dalam hal ini tujuan pendidikan dibagi menjadi beberapa domain (ranah, kawasan) dan setiap setiap domain tersebut dibagi kembali ke dalam pembagian yang lebih rinci lagi, tujuan pendidikan dibagi ke dalam tiga domain yaitu, (1) Ranah Kognitif, (2) Ranah Afektif, (3) Ranah Psikomotor. Bloom membagi domain kognisi menjadi 6 tingkatan yaitu (1) pengetahuan, (2) pemahaman, (3) aplikasi, (4)analisis, (5) sintesis, dan (6) evaluasi. Dalam tingkatan pemahaman berisikan kemampuan menangkap arti dan makna, dan lebih luas lagi yaitu kemampuan mendemostrasikan fakta dan gagasan mengelompokkan dengan mengorganisir, membandingkan, menerjemahkan, memberi deskripsi, dan menyatakan gagasan utama (Arifin, 2012).

Biblioterapi adalah penggunaan bacaan untuk mengobati penyakit gangguan-gangguan psikologis (Kartono dan Guloo, 1987). Biblioterapi sebagai suatu program aktifitas yg

berdasarkan proses pada pembaca yg membutuhkan interaksi dan informasi secara kreatif (Monroe,Margaret dan Rubin, Rhea J, 1975). Biblioterapi merupakan suatu upaya mengatasi masalah melalui media buku, penggunaan terapi pustaka sebagai salah satu alternatif terapi dalam menangani berbagai permasalahan pada remaja perlu dipertimbangkan, hal ini disebabkan karena biblioterapi dapat merangsang remaja untuk berfikir, mudah, murah, dan dapat dilakukan kapan saja serta melibatkan kemandirian dan partisipasi remaja sendiri secara penuh sehingga efektivitas hasilnya cukup baik (Hidayah dkk, 2016). Biblioterapi merupakan aplikasi langsung dari metode membaca untuk mempengaruhi perubahan dalam karakter/perilaku seseorang, hal ini didasarkan pada asumsi bahwa terdapat kesamaan yangkuat antara karakter tokoh cerita dalam buku dengan pembaca memungkinkan menjadi role model yang dapat memiliki efek kuratif, menanamkan prinsip baik maupun buruk sangat mungkin melalui kegiatan membaca (Dewi, 2014).

\section{METODE}

Berdasarkan judul penelitian yaitu biblioterapi untuk meningkatkan pemahaman labelling negatif maka peneliti 
menggunakan metode penelitian kuantitatif (Sugiyono, 2013). Dalam penelitian ini menggunakan desain penelitian pre-experimental design dengan bentuk one group pretest postest design yang dilaksanakan pada satu kelompok saja tanpa kelompok pembanding, model ini menggunakan tes awal sehingga besarnya efek dari eksperimen dapat diketahui dengan pasti (Arikunto, 2009). Tujuan dari desain penelitian ini adalah untuk mengetahui perbandingan skor pemahaman dengan menggunakan teknik biblioterapi, dengan mengukur tingkat pemahaman labelling negatif siswa sebelum perlakuan (pre-test) dan setelah diberikan perlakuan (posttest). Subjek penelitian adalah sumber yang akan diteliti untuk menjalankan suatu penelitian dan mendapatkan data dari subjek yang diteliti tersebut. Dalam penelitian ini menggunakan metode pengampilan subjek sebanyak 7 siswa yang berasal dari kelas VII-D.

Dalam desain ini menggunakan alat pengumpul data yaitu angket tertutup yang diberikan dalam satu kelompok subjek sebanyak dua kali yaitu sebelum dan sesudah eksperimen. Pertama dilakukan pengukuran pre-test dengan menggunakan angket labelling lalu dianalisis dan subjek yang terpilih akan diberikan perlakuan dalam jangka waktu tertentu dengan metode bimbingan kelompok kemudian dilakukan pengukuran kembali posttest dengan angket labelling.

Dalam analisis data ini dilakukan dengan SPSS dengan menggunakan teknik statistik non-parametrik yaitu uji Wilcoxon karena merupakan jenis data ordinal dan juga memperhatikan selisih nilai antara angka positif dan negative untuk melihat perbedaan skor pemahaman tentang labelling negatif sebelum dan sesudah adanya perlakuan berupa biblioterapi.

\section{HASIL DAN PEMBAHASAN}

Penelitian ini dilakukan pada 7 siswa yang menjadi subjek penelitian yang berasal dari kelas VII-D. Data yang disajikan ini merupakan data pengukuran awal (pre-test) yang digunakan untuk mengetahui kondisi awal siswa yang akan dijadikan subjek penelitian. Pretest ini dilakukan pada kelas VII-D SMP dengan diberikan angket labelling. Dari hasil penyebaran pretest ini kemudian dikategorikan menjadi 3 kategori yaitu tinggi, sedang, dan rendah.

Penyebaran angket pre-test ini bertujuan untuk mengetahui skor pemahaman labelling negatif siswa sebelum diberikan teknik bibioterapi, kemudian siswa yang masuk dalam kategori rendah akan dijadikan sebagai subjek penelitian, selain kategori rendah adapun kategori tinggi dan sedang yang diperoleh dari perhitungan mean dan standart deviasi sebagai berikut.

\begin{tabular}{|c|c|c|c|}
\hline \multicolumn{4}{|c|}{ Hasil Pre-Test Angket Labelling } \\
\hline No & Nama & Skor & Kategori \\
\hline 1 & $\mathrm{AC}$ & 78 & Rendah \\
\hline 2 & LNM & 84 & Rendah \\
\hline 3 & MIK & 79 & Rendah \\
\hline 4 & RMN & 81 & Rendah \\
\hline 5 & SMU & 79 & Rendah \\
\hline 6 & SF & 84 & Rendah \\
\hline 7 & WAW & 79 & Rendah \\
\hline
\end{tabular}

Setelah melaksanakan pemberian perlakuan teknik biblioterapi pada subjek penelitian yang berjumlah tujuh siswa kelas VII-D yang termasuk dalam kategori rendah dalam pemahaman mengenai labelling berdasarkan hasil penghitungan skor angket labelling pre-test yang telah diberikan sebelumnya. Subjek penelitian ini kemudian diberikan angket labelling post-test yang berisi sama dengan angket sebelumnya, tujuan dari pemberian angket post-test ini adalah untuk mengetahui adanya perubahan atau perbedaan skor pemahaman siswa setelah diberikan perlakuan dengan sebelum diberikan perlakuan. Pemberian post-test ini dilakukan pada tanggal 24 Mei 2017 dengan memberikan angket labelling pada saat pelaksanaan pertemuan ke empat dalam kegiatan pemberian perlakuan. Adapun data yang diperoleh dari hasil post-test sebagai berikut.

Hasil Post-Test Angket Labeling

\begin{tabular}{|c|c|c|c|}
\hline No & Nama & Skor & Kategori \\
\hline 1 & AC & 123 & Tinggi \\
\hline 2 & LNM & 100 & Sedang \\
\hline 3 & MIK & 100 & Sedang \\
\hline 4 & RMN & 86 & Sedang \\
\hline 5 & SMU & 101 & Sedang \\
\hline 6 & SF & 85 & Sedang \\
\hline 7 & WAW & 108 & Sedang \\
\hline
\end{tabular}

\section{PEMBAHASAN}

Penelitian biblioterapi untuk meningkatkan pemahaman labelling negatif ini mengambil subjek dengan cara melihat skor hasil dari tes awal dengan dikelompokkan menjadi kategori tinggi, sedang, dan rendah, untuk kategori rendah selanjutnya dikumpulkan untuk diberi perlakuan dengan teknik biblioterapi. Penentuan kategori tersebut didapatkan dari perhitungan mean, standar deviasi (SD), nilai kategori rendah yaitu 84,83 ke bawah, kategori sedang yaitu 84,83 sampai 104,23 , dan kategri tinggi yaitu 104,23 ke atas. Siswa yang masuk kategori rendah dikumpulkan untuk melaksanakan bimbingan kelompok, bimbingan kelompok sendiri memiliki pengertian yaitu bantuan kepada kelompok-kelompok kecil yang terdiri atas 2-10 peserta didik/konseli agar mereka mampu melakukan pencegahan masalah, pemeliharaan nilai-nilai, dan pengembangan keterampilan-keterampilan hidup yang dibutuhkan. (Kementerian Pendidikan dan Kebudayaan,2016)

Dari tes awal/pre-test yang diberikan kepada 32 siswa kelas VII-D diperoleh 7 siswa dengan kategori rendah, 19 siswa dengan kategori sedang, dan 6 siswa dengan kategori tinggi. Cara selanjutnya 7 siswa yang memiliki kategori rendah berdasarkan hasil pre test tersebut yaitu AC dengan skor 78, LNM dengan skor 84, MIK dengan skor 79, RNM dengan skor 81, SMU dengan skor 79, SF dengan skor 84, dan WAW dengan skor 79 kemudian diberikan bimbingan kelompok dengan teknik biblioterapi yaitu memberikan bahan bacaan bagi siswa dalam inti kegiatannya. Bimbingan kelompok ini dilakukan sebanyak empat kali untuk membantu siswa memiliki pemahaman labelling negatif yang meliputi pengertian 
dan jenis labelling, pemberian cap negatif yang umum di masyarakat, dan labelling negatif yang menghancurkan sebuah pertemanan.

Ketiga indikator tersebut dibahas satu persatu dengan menggunakan bahan bacaan yang berkaitan dengan masing-masing indikator yang diberikan pada saat pelaksanaan bimingan kelompok. Dalam pelaksanaan bimbingan kelompok dengan teknik biblioterapi ini awalnya siswa masih terlihat bingung dan belum memahami kegiatan ini, hal ini disebabkan karena semua subjek penelitian belum pernah melakukan bimbingna kelompok sebelumya. Mereka juga masih belum begitu terbuka dan sulit untuk diajak diskusi pada awalnya, namun hal ini dapat diatasi dengan cara melakukan pendekatan ke siswa dan memberikan penjelasan mengenai bimbingan kelompok yang dilakukan. Dalam pelaksanaan bimbingan kelompok dengan teknik biblioterapi ini secara umum permasalahan siwa berkaitan dengan belum pahamnya mereka mengenai istilah labelling dan belum pahamnya mengenai dampak apa yang akan muncul dengan adanya labelling negatif.

Setelah diberikan perlakuan subjek penelitian yang berjumlah 7 siswa mengalami kenaikan skor dilihat dari hasil analysis angket post-test, AC menglami kenaikan skor sebanyak 45 poin, LNM mengalami kenaikan skor sebanyak 16 poin, MIK mengalami kenaikansebanyak 21 poin, RMN mengalami kenaikan skor sebanyak 5 poin, SMU sebanyak 22 poin meningkat, Sf sebanyak 1 poin, dan WAW mengalami peningkatan skor sebanyak 29 poin.

Adanya perbedaan pemahaman siswa tentang labelling negatif juga dierkuat dari hasil analisis non-parametric dengan menggunakan uji Wilcoxon yang menunjukkan perubahan pemahaman siswa yang awalnya rendah meningkat menjadi lebih tinggi. Perubahan ini dapat dilihat dari hasil uji Wilcoxon yang hasilnya menunjukkan bahwa terdapat perbedaan skor antara sebelum diberikan perlakuan dan sesudah diberikan perlakuan. Hal ini berarti bahwa penerapan biblioterapi berpengaruh positif dalam meningkatkan pemahaman siswa tentang labelling negatif. Sehingga dapat dikatakan bahwa penerapan biblioterapi dapat meningkatkan pemahaman tentang labelling negatif pada siswa kelas VII-D SMPN 2 Dlanggu

\section{PENUTUP}

\section{Simpulan}

Hasil penelitian dapat mengungkap bahwa terjadi peningkatkan pemahaman labelling negatif pada siswa yang berjumlah tujuh yang dipakai sebagai subjek penelitian. Kesimpulan ini berdasarkan dari hasil uji Wilcoxon yaitu diketahui bahwa 7 siswa yang bertindak sebagai $\mathrm{N}$ (banyaknya pasangan yang menunjukkan perbedaan) dan ranking negatif berjumalh 0 yang bertindak sebagai $\mathrm{x}$ (banyaknya tanda yang lebih sedikit). Dengan ketentuan $\mathrm{N}=7$ dan $\mathrm{x}=0$, maka diperoleh $\rho$ kemungkinan harga dibawah $\mathrm{Ho})=0.018$. Bila dalam ketetapan $\alpha$ (taraf kesalahan) sebesar 5\% adalah 0.05 maka $0.018<0.05$, jadi dapat disimpulkan bahwa Ho ditolak dan Ha diterima. Setelah diberikan perlakuan biblioterapi terdapat perbedaan skor antara tes awal/pre- test dengan tes akhir/post-test pemahaman siswa tentang labelling negatif. Sehingga dapat dikatakan bahwa penerapan biblioterapi dapat meningkatkan pemahaman tentang labelling negatif pada siswa kelas VII-D SMPN 2 Dlanggu.

\section{Saran}

Dari penelitian yang sudah dilakukan maka peneliti dapat memberikan saran yaitu penelitian ini dapat dijadikan sebagai acuan dan dapat dikembangkan dalam melakukan penelitian selanjutnya yang berkaitan dengan teknik biblioterapi maupun labelling. Dalam penelitian ini masih memiliki keterbatasan seperti focus penelitan yang masih terbatas pada aspek kognisi berupa pemahaman tentang labelling negatif bukan pada perilaku pemberian label negatif. Untuk itu diharapkan peneliti lain di waktu selanjutnya mempertimbangkan lebih luasnya subjek penelitian, lamanya waktu pertemuan, penjalinan hubungan yang baik dengan siswa, serta juga memfokuskan penelitian pada perilaku pemberian label negatif dengan menggunakan instrument yang lebih mendukung.

\section{DAFTAR PUSTAKA}

Bandung : PT. Remaja Rosdakarya

Arikunto,Suharsimi.2009. Manjemen Penelitian. Jakarta: PT.Rineka Cipta

Arikunto,Suharsimi.2009.Manajemen Penelitian.Jakarta : Rineka Cipta

Del rio,Asuncion alvarez,dkk.2016.Bibliotherapy An Experience For Children With Cancer. Journal of Reading and Bibliotherapy.

Dewi,Noviana.2014.Metode Biblioterapi Untuk Peningkatan Karakter Tanggung Jawab. Jurnal Psikologi. Volume 40,No 3

Herimanto dan Winarno. 2008. Ilmu Sosial dan Budaya Dasar. Jakarta: Bumi Aksara

Kartono,Kartini dan Guloo, Dali.1987. Kamus Psikologi. USA:Universitas Michigan

Kementerian Pendidikan dan Kebudayaan.2016.Panduan

Operasional Bimbingan dan Konseling di Sekolah Menengah Pertama

Monroe,Margaret;Rubin,Rhea J.1975.Bibliotherapy Trends In The United States.Journal of Libraries And Information Services

Nur'aini,Aliyah dan Ahmadi,Dadi. 2015. Teori Penjulukan. Jurnal Mediator. Volume 6 hal. 2

Qorny,Wulan.2015.Distorsi Kognitif Dalam Keseharian (online).

Tersedia

http://wulanqorny.blogspot.co.id/2015/05/distorsikognitif-dalam-keseharian.html

Sarwono, Sarlito W. 2014. Psikologi Lintas Budaya. Jakarta:Rajawali Pers 
Shechtman,zipora;Shfrir,rivka nir.2008.The Effect Of Affective Bibliotherapy On Clients Functioning In Group Therapy. Journal of group psychotherapy. Volume 58,iss 1

Sugiyono. 2013. Metode Penelitian Pendidikan (Pendekatan Kuantitatif, Kualitatif, R\&D). Bandung : Alfabeta

Sugiyono. 2014. Metode Penelitian Kuantitatif Kualitatif dan R\&D. Bandung: Alfabeta

Tim. 1990. Kamus Besar Bahasa Indonesia. Jakarta: Balai Pustaka

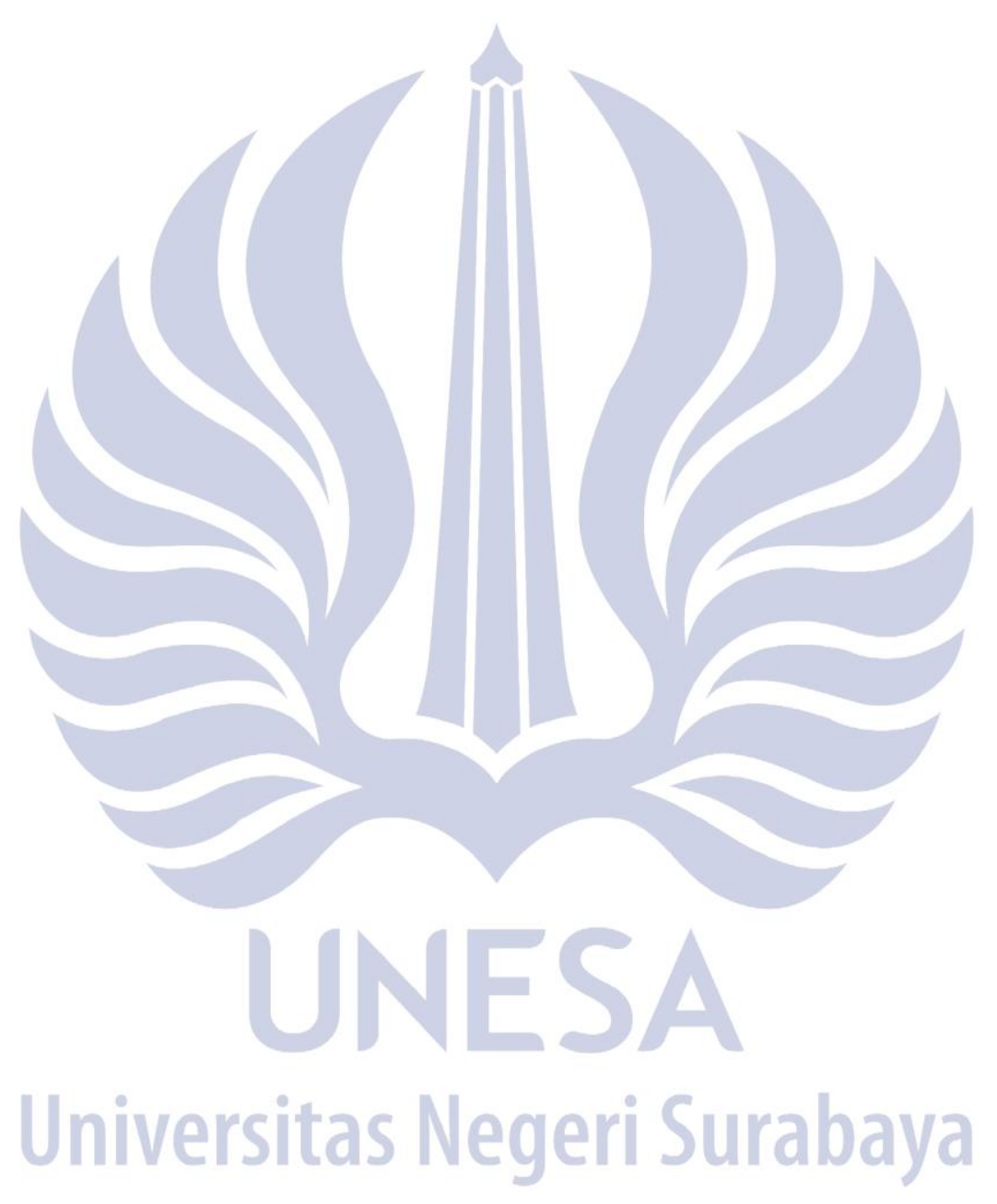

